\title{
50 Yaş ve Üstü Yerli Turistlerin Seyahat Motivasyonu ve Seyahat Karakteristiği
}

\author{
Ebru Zencir Çiftçi $i^{1 *}$ iD \\ ${ }^{1}$ Anadolu Üniversitesi, Turizm Fakültesi, Eskişehir, Türkiye, ezencir@anadolu.edu.tr, ORCID: 0000-0001-6668-9961
}

Öz

Bu çalışmanın amacı 50 yaş ve üzeri yerli turistlerin seyahat motivasyonu ve karakteristiğinin ortaya çıkarılmasıdır. Pandemi sonrası turizmin ivme kazanması için pazar bölümlerine özel planlar oluşturulması yerinde olacaktır. Bu çalışmada, turizm pazarında önemli bir yere sahip olan ileri yaş grubunun motivasyon unsurları ve seyahat karakteristiğinin belirlenmesi amaçlanmıştır. Araştırmada nicel veri toplama ve analiz tekniklerinden faydalanılmıştır. Veri toplamada anket tekniğinden yararlanılmış olup, anketler pandemi dolayısıyla hem yüz yüze hem de çevrimiçi olarak 01.03.202131.03.2021 tarihleri arasında kolayda örneklem yoluyla toplanmıştır. Toplanan 522 anketin 130'u geçersiz kabul edilerek 392 anket değerlendirilmeye alınmıştır. Elde edilen verilere tanımlayıcı istatistikler, t testi ve ANOVA uygulanmıştır. Araştırma sonucunda 50 yaş ve üstünün seyahat motivasyonu boyutları nostalji ve değer paylaşımı, öğrenme, özbenlik arayışı, rahatlama, fiziksel aktivite, bağlılık arayışı, bağlanma arayışı ve maneviyat arayışı olarak sıralanmıştır. 50 yaş ve üstünün seyahat yeri seçiminde en önemli bilgi kaynağının sosyal medya olduğu, yalnız seyahat etmeyi tercih ettikleri, otel yerine aile ve arkadaş yanında konakladıkları ve seyahatlerinde fiziksel aktivite başta olmak üzere pek çok etkinliğe katıldıkları belirlenmiştir.

Anahtar Kelimeler: 50 Yaş ve Üstü, Ileri Yaş, Seyahat Motivasyonu, Seyahat Karakteristiği, Yerli Turist

\section{Travel Motives and Characteristics of Domestic Tourists over the Age of 50}

Abstract

The aim of this study is to reveal the travel motivation and characteristics of domestic tourists over the age of 50. In order for tourism industry to gain momentum after the pandemic, it would be appropriate to plan the future for the market segments. In this study, the motivational elements and travel characteristics of the older age group, which has an important capacity in tourism market will be determined Quantitative data collection and analysis techniques were used in the research. Questionnaire technique was used in data collection, and the surveys were collected face to face and online by convenience sampling, between 01.03.2021-31.03.2021, due to the pandemic. Of the 522 collected questionnaires, 130 were considered invalid and 392 data were evaluated. Descriptive statistics, $t$ test and ANOVA were applied to the obtained data. As a result of the research, the travel motivation dimensions of over 50 year olds are listed as nostalgia and value sharing, learning, selfseeking, relaxation, physical activity, attachment seeking, connection seeking and spirituality seeking. It has been determined that social media is the most important source of information in the selection of travel destinations for 50 year olds and over, they prefer to travel alone, stay with family and friends instead of hotels, and participate in many activities, especially physical activity during their travels.

Keywords: Over 50, Older Age, Travel Motivation, Travel Characteristics, Domestic Tourist
Araştırma Makalesi

Cilt 5, Sayı 2, 2021

ss. $305-326$

Gönderim: 01.05.2021

1. Düzeltme: 28.06 .2021

2. Düzeltme: 04.08 .2021

3. Düzeltme: 12.09 .2021

Kabul Tarihi: 13.09.2021

\section{Research Article}

Vol 5, No 2, 2021

pp. $305-326$

Received : 01.05.2021

Revision1: 28.06.2021

Revision2: 04.08.2021

Revision3: 12.09.2021

Accepted: 13.09.2021

\section{Önerilen Atıf/Suggested Citation}

Zencir Çiftçi, E. (2021). 50 Yaş ve Üstü Yerli Turistlerin Seyahat Motivasyonu ve Seyahat Karakteristiği. Güncel Turizm Araştırmaları Dergisi, 5(2), 305-326.

**Sorumlu yazar e-posta: ezencir@anadolu.edu.tr 


\section{GíRIŞ}

Turizm sektörü dünyada yaşanan pek çok olaydan etkilenebilen kırılgan bir yapıya sahiptir. Terör saldırıları, savaşlar, devlet politikalarındaki düzenlemeler ve ekonomik gelişmeler bunlardan sadece birkaçıdır. Bahsi geçen bütün bu olaylar turizm sektöründe bir kriz ortamı yaratmakta ve yeni tedbirler alınmasını gerekli hale getirmektedir. 2019 yılından itibaren bütün dünyayı etkisi altına alan Covid 19 salgını, eğitimden sağlığa her sektörü etkilediği gibi turizme de büyük darbe vurmuştur. Son bir yılda bütün dünyada turizm durma noktasına gelmiş, Türkiye'de oda doluluk oranları önceki senelere göre \%80 düşüş göstermiştir (turob.org, E.T. 25 Şubat 2021).

Türkiye'de turizmin ülke ekonomisi üzerinde önemli paya sahip olması, bu gibi krizlerin en kısa sürede kontrol altına alınmasını gerekli kılmaktadır. Kriz durumunun giderilmesi bu noktada en çok tercih edilen durum olmakla birlikte pandemi, sektörler üzeri bir durumdur ve etkilerinin bir süre daha devam edeceği söylenebilir. Dolayısıyla iş kolları, devamlılığı sağlamak için farklı yöntemleri deneme yoluna gitmektedir. Covid-19'un turistlerin seyahat motivasyonu üzerindeki etkisini belirlemek ve yeni motivasyonlara göre turizm çalışmalarını yürütmek, turizm sektöründe ele alınan önerilerden bir tanesidir (Aebli vd., 2021). Birleşmiş Milletler Dünya Turizm Örgütü devlet politikaları bağlamında turizm sektörüne sağlanabilecek katkılardan bahsetmekle birlikte, yaşanmakta olan bu krizin atlatılabilmesi için tek bir kesin çözümün olmadığını belirtmekte, ulusal ve yerel düzeyde taktiklerin uygulanmasını önermektedir (Collins Kreiner ve Ram, 2021). Bu bağlamda, Türkiye turizm sektöründe de yeni pazarlara yönelme pandeminin etkilerini azaltmak için etkili yöntemlerden biri olabilir. Bu noktadan hareketle bu araştırmada potansiyel müşteriler dikkate alınarak değişen seyahat motivasyonlarının ve karakteristiklerinin incelenmesi gerekli görülmüştür.

Ülkelerin Covid-19 salgını sürecinde uyguladıkları ilk tedbirlerden biri yurt dışı seyahat yasakları olmuştur. İnsanlar yurt dışına gidemediği gibi yurtdışından gelişlerin de kapatıldığı pek çok uygulama yaşanmıştır. Diğer taraftan günlük hayatın devam etmesi konusunda devlet destekleri ve teşvikleri yürütülmektedir (covid19.saglik.gov.tr/, icisleri.gov.tr, E.T: 28.07.2021). Bu gelişmeler neticesinde insanların seyahat konusunda daha temkinli olduğu varsayılabilir, diğer taraftan günlük hayat devam etmektedir. Türkiye'de pandemi sürecinin başlaması 2020 yılının Mart ayında gerçekleşmiş olup bir yıldan uzun süredir kapalı, yarı kapalı, kontrollü hayatlar yaşanmaktadır. Son dönemde ise illere göre farklı kontrol politikaları uygulanmıştır. Bu gelişmelerle birlikte günlük hayatın devam etmesi için çeşitli tedbirler alınmakta, bütün sektörler ve iş kolları içinde bulunduğu ortamı pandemi koşullarına göre düzenleme çalışmaları gerçekleştirmektedir. Kültür ve Turizm Bakanlığı da konu ile ilgili çok çeşitli uygulamaları hayata geçirmiş ve güvenli seyahat ortamı yaratmak için çalışmalar ortaya koymuştur (tga.gov.tr, E.T:29.07.2021). Yarı kapasite çalışma ve sürekli dezenfeksiyon bu önlemlerin başında gelmektedir. Bu faaliyetler her ne kadar turizmi yaşatsa da yarı kapasite çalışma söz konusudur. Bu nedenle turizm işletmelerinin pazarı çok iyi analiz ederek turizm faaliyetlerini 
mümkün olduğunca geniş bir zaman dilimine yaymalıdır. Türkiye'de turizmin büyük oranda deniz kum güneş denklemine dayanmasından dolayı bir süredir "ölü sezon" olarak ifade edilen dönemlerde farklı müşteri gruplarına hizmet verilmesi yoluna gidilmiştir. Örneğin Antalya gibi turizm merkezlerinde sezon dişı dönemde özellikle üçüncü yaş turistleri ağırlanarak bu denge sağlanmıştır. İçinde bulunulan dönemde de benzer bir uygulamanın gerçekleştirilebileceği düşüncesinden yola çıkarak bu çalışmada sekteye uğrayan turizm sektörünün canlanmasında ileri yaş grubunun incelemesine karar verilmiştir. Çalışmada 50 yaş ve üzeri yerli turistlerin seyahat motivasyonu ve karakteristiğinin ortaya çıkarılması amaçlanmıştır. Böylece turizm pazarında önemli bir yere sahip olan ileri yaş grubunun motivasyon unsurları ve seyahat karakteristiğinin yerli turistler bağlamındaki durumuna ilişkin bir kesit ortaya konabilecektir. Çalışma kriz ortamında bir alternatif bakış açısı sunması bakımından önemlidir.

\section{Alanyazın}

Seyahat motivasyonu konusu turizm alanında önem verilen konulardandır. İnsanların seyahat etmesi turizmin temelini oluşturduğu için motivasyon kaynakları inceleme konusu olmuştur (Demir ve Kozak, 2011). Ancak seyahat algısı, beklentileri ve dolayısıyla motivasyonu tüketiciler açısından farklılık gösterebilmektedir. Bu noktada pazar bölümleri üzerine araştırmalar tercih edilir olmuştur. Bu sayede hedef kitlelerin istek ve beklentilerine ilişkin daha isabetli tahminler elde edilmeye başlanmıştır. İleri yaş grubu bu kesimlerden bir tanesidir.

Kimi kaynaklarda üçüncü yaş olarak ele alınmakla birlikte, çalışmalar genel olarak değerlendirildiğinde ileri yaş olarak ifade edilebilecek kesimin daha fazla turizm potansiyeline sahip olduğu anlaşılmaktadır (Card, 2003; Pestana vd., 2020). Üçüncü yaşın seyahatlerinden beklentileri ve bu beklentilerin karşılanması dünya nüfusunun yaşlanmasıyla daha fazla önem kazanmaya başlamıştır. Öyle ki Dünya Sağlık Örgütü tarafından yürütülen Yaşlı Dostu Şehir uygulamaları hayata geçirilmiştir ve Türkiye'de de çeşitli belediyelerde uygulanmaya başlanmıştır (Kozak vd, 2019). Böylece yaşlılara uygun seyahat ve konaklama imkanlarının oluşturulması hedeflenmiş ve yaşlı hakları gözetilmiştir. Diğer taraftan "yaşlı" olarak ifade edilen kesimi kimlerin oluşturduğu ayrı bir tartışma konusudur. Dünya Sağlık Örgütü yaşlılı̆̆ın başlangıcı olarak dünya genelinde emeklilik yaşı olan 65 yaşını kriter alırken Birleşmiş Milletler 60 ve üstü yaşı temel almaktadır. Diğer taraftan yaşlılık psikolojik, sosyal ve biyolojik olarak da değerlendirilebilmekte, bakış açısına göre farklı tanımlar yapılmaktadır (Samancı Tekin ve Kara, 2018). Bakış açısı "yaşlılık" ifadesinin de farklı algılanmasına, değişmesine neden olmuştur. Turizm açısından ele alındığında ise alanyazında yaşlılık ifadesi tercih edilmemektedir. Turizm araştırmalarında "ileri yaş" çalışmalarının 50'li yaşlara kadar gerilediği görülmektedir (Möller vd., 2007) Gürsoy'un (2016) 50+ otel kavramını ele alması 50 yaş üzeri çalışmaların güncel kavramlar arasına girdiğini gösterir nitelikte olup, ayrıca sektörel anlamda 50 yaş üstünün turizm hareketliliğinin artışıyla da ilişkilendirilebilir. Anderson ve Langmeyer (2016) 50 yaş üstündeki ve altındaki turistlerin davranışlarını incelediği 
çalışmasıyla 50 yaşın kritik bir nokta olduğuna işaret etmiştir. Persana vd.'nin (2020) çalışmasında 1998-2017 tarihleri arasında yaş aralığı belirtilmemekle birlikte ileri yaş turizmini inceleyen araştırmalar incelenmiş ve 700 temel eser tespit edilmiştir.

Çalışma kapsamında ileri yaş grubu olarak pek çok farklı ifade taranmıştır. Anahtar kelime olarak yaşlı, büyük, yaşlanan, ileri yaş, kıdemli, gri pazar, emekli, üçüncü yaş, olgun pazarı (elderly, older, aging, aged, senior, silver market, retired, third age, mature market) gibi pek çok ifade kullanılmıştır (Dann, 2002; Avcıkurt, 2003; Ashworth vd., 2005, Nimrod ve Rotem, 2012; Vigolo ve Confente, 2014). Hung ve Lu (2016) konuyu ele alan 52 makaleyi incelemiş ve alanyazındaki bu çalışmalarda yaş aralıklarının genellikle 55 yaştan başladığını, ancak 50 yaşa kadar düşüldüğünü tespit etmişlerdir. Turizm pazarında sosyo demografik özelliklerdeki değişimi inceleyen çalışmalarda 50-65 yaş arası kişiler genç-yaşlılar (young senior) olarak ele alınmaktadır (Moutinho, 2000: 4). Turizm çalışmalarında ileri yaşın bu kadar aşağıdan başlatılmasının temel nedeni aktif yaşamla açıklanmaktadır. 50 yaş ve üzeri kişiler fiziksel olarak yeterince aktif olabilen bir grup olarak değerlendirilebilir. Ayrıca bu grubun hayata yeni başlamış, iş bulma, yuva kurma gibi kaygılar taşıyan gençlere ve işinde yükselme gibi iş odaklı hedefleri olan orta yaş grubuna göre daha fazla seyahat potansiyeline sahip oldukları söylenebilir. Bu, bir anlamda insanların ileri yaşlarda elde edebildiği bir imkandır. Bu nedenle bu çalışmada ele alınan gruba alanyazında da yer bulan "ileri yaş" ifadesi kullanılacaktır.

İleri yaşın turizm tercihleri, boş zaman faaliyetleri, tüketim tercihleri ve motivasyonları gibi konular sıkça incelemelere konu olmuştur (Hsu vd., 2007, Hung ve Lu, 2016; Pestana vd., 2020; Deikmann vd., 2020). Seyahat motivasyonları da destinasyonlara, ülkelere ve ileri yaş içindeki yaş gruplarına göre incelenen konulardandır. İleri yaş turistlerin seyahat motivasyonunda genellikle itme ve çekme faktörleri ele alınmıştır. Alen vd. (2016) alanyazındaki ileri yaş turistlerin seyahat motivasyonunu konu alan pek çok araştırmayı incelemiştir. Bu çalışmaya göre ileri yaş turistlerde tespit edilen itme faktörleri rahatlama, sosyalleşme, aileyle vakit geçirme şeklindeyken çekme faktörleri tarihi ve doğal çekicilikler, sanatsal ve kültürel aktiviteler, konaklama imkanları, temizlik, güvenlik gibi çeşitli boyutları kapsamaktadır. Çalışmaların geneline bakıldığında ise farklı boyutların da dikkate alındığ1 görülmektedir. Örneğin Diekmann vd. (2020) ileri yaştakilerin seyahat motivasyonunu fiziksel aktivitelere katılma (yürüyüş, jimnastik, su jimnastiği, dans vb.), sosyal aktivitelere katılma (çalıştaylar, oyunlar, grup gezileri, sosyal etkinlikler vb.), bilimsel aktivitelere katılma (okuma, gezi programına katılma, kelime oyunları oynama vb.), rahatlama aktivitelerine katılma (güneşlenme, masaj, yoga vb.) ve alışveriş olmak üzere beş grupta incelemiştir. Sellick'in çalışması ise en kapsamlı çalışmalardan olması bakımından dikkati çekmektedir. Sellick (2004) seyahat motivasyonunu öğrenme heveslisi olanlar, özbenlik arayanlar, rahatına düşkünler, bağlantı ve üstünlük arayanlar, ruh ve teselli arayanlar, fiziksel aktivite sevenler, bağlılık arayanlar, nostaljik anılar arayanlar, nesiller arası bağlantı kurmak isteyenler ve sosyal paylaşımcılar olmak üzere 10 boyutta incelemiştir. Jang vd. (2009) Tayvan'da gerçekleştirdikleri çalışma sonucunda ileri yaşı en çok motive eden unsurun yenilik 
arayışı olduğunu aktarmıştır. Bunu özbenlik arayışı, ego-pekiştirme, sosyalleşme ve dinlenip rahatlama faktörleri izlemektedir. Araştırmada ayrıca yaş, cinsiyet, medeni durum, çalışma durumu ve eğitim durumunu da motivasyon üzerinde etkili olduğu belirtilmiştir. Wijaya vd. (2018) Endonezya'da gerçekleştirdikleri araştırmada ileri seyahat motivasyonunun kişisel gelişim, rahatlama ve ilişki arayışı faktörleri altında toplandığını tespit etmiştir. Bu çalışmalar ileri yaş grubunda seyahat motivasyonunun ülkelere göre farklı öncelikler sergilediğini gösteren örneklerdir. Yerli turistler üzerine gerçekleştirdiği çalışmasında Sert (2019) üçüncü yaş turistlerinin en yaygın itme motivasyonlarının dinlenme ve rahatlama, kaçış, yenilik arayışı, sosyal etkileşim, fiziksel egzersiz, sağlık, nostalji, arkadaş ve akraba ziyareti; çekme motivasyonlarının ise hijyen ve temizlik, güvenlik, iklim, maliyet, ulaşım kolaylı̆̆ı, alışveriş imkanları, tıbbi olanaklar, tarihi ve kültürel çekicilikler, doğal çekicilikler olduğunu belirlemiştir.

İleri yaş grubuna ilişkin sıkça ele alınan diğer konu seyahat karakteristiğidir. Seyahat karakteristiği ile ilgili çalışmalar incelendiğinde, genel soruların yanı sıra yaş kaynaklı soruların da yönlendirildiği görülmüştür. Anderson ve Langmeyer (1982) 50 yaş ve üstü turistlerin demografik özelliklerini inceleyerek, bu özelliklerin seyahat alışkanlıklarını nasıl etkilediğini tespit etmeye çalışmıştır. Yazarlar araştırmada seyahat amacı, seyahatlerde en çok tercih edilen araç tipi, seyahate ayrılan bütçe, geceleme, acenta kullanımı gibi sorulara da yer vermiştir. Kılıçlar vd. (2017) 65 yaş üstünü incelediği çalışmada ziyaret amacını akraba/arkadaş ziyareti, alışveriş, din/hac, eğitim, gezi, eğlence, sportif ve kültürel aktiviteler, sağlık ve iş amaçlı kategorilerinde ele almıştır. Alen vd. (2016) ise genel bir tarama sonucunda seyahat karakteristiğini belirlemeye yönelik en sık sorulan soruları derlemiş ve araştırmasında bu soruları kullanmıştır. Buna göre konaklama şekli, kimlerle seyahat edildiği, seyahat tipi (kimin organize ettiği), seyahate hazırlanma süresi, bilgi kaynağı, seyahat uzunluğu, ulaşım aracı, seyahat harcaması ve seyahatte gerçekleştirilen aktiviteler seyahat karakteristiğinin belirlenmesinde en sik sorulan sorular olmuştur. Bu sorularla seyahat karakteristiğine ilişkin yeterli bilginin elde edildiği söylenebilir.

\section{YÖNTEM}

Araştırmanın temel amacı 50 yaş ve üzeri yerli turistlerin seyahat motivasyonlarını ve seyahat karakteristiklerini belirlemektir. Böylece Covid-19 salgını ile birlikte önemli bir düşüş yaşanan turizm hareketlerinin canlandırılması yönünde isabetli adımların atılması mümkün olabilecektir. Araştırmada seyahat motivasyonu, seyahat karakteristiği ve demografik özelliklerin birbirleri ile karşılaştırılması alt amaçlar olarak belirlenmiştir.

Bilindiği gibi Covid-19 insanların günlük hayatını değiştirmiş, uzmanlar "yeni normal" hayata uyum sağlanması gerektiğini belirtmiştir. Özellikle yurt dişı uçuşların kalkması, gidiş-geliş hareketliliğinde önemli bir kısıt haline gelmiştir. Diğer taraftan devlet politikaları gereği yurt dışı uçuşlar önerilmemekte hatta bazı destinasyonlardan geliş gidişlere yasak getirilmektedir. Genel olarak yurt dışı uçuşlarının tutarsız bir süreç içerisinde olduğu söylenebilir. Bu noktada, yerli turist Türkiye'de turizmin canlanmasında önemli bir kaynak olarak değerlendirilebilir. Potansiyelin doğru 
değerlendirilebilmesi için ise yerli turistlerin seyahat motivasyonlarının ve nasıl seyahat ettikleri, bir diğer ifadeyle seyahat karakteristiklerinin bilinmesi gerekmektedir.

Seyahat motivasyonu kavramı neredeyse turizm kadar eski bir konu olmakla birlikte, dönemsel olarak farklılık göstermiştir. Sosyal bilimlerin doğası gereği insanların tutum ve davranışları yaşanan olaylardan etkilenebilmekte ve değişebilmektedir. Günümüzde yaşanan ve bütün dünyayı etkisi altına alan olumsuz koşulların da seyahat motivasyonları üzerinde etkili olabileceği tahmin edilebilir. Diğer taraftan seyahat şekilleri de farklılaşmış olabilir. Bu noktadan hareketle bu çalışmada yerli turistin seyahat motivasyonu ve seyahat karakteristiği araştırılacak, araştırma 50 yaş ve üzeri ile sınırlandırılacaktır. Belirtilen amaç doğrultusunda üç temel hipotez ve toplamda 16 alt hipotez test edilmiştir.

$H_{1} 50$ yaş ve üzeri kişilerin seyahat karakteristiği seyahat motivasyonlarına göre farklılık göstermektedir.

$H_{2:} 50$ yaş ve üzeri kişilerin seyahat motivasyonları demografik özelliklerine göre farklılık göstermektedir

$H_{3:} 50$ yaş ve üzeri kişilerin seyahat karakteristikleri demografik özelliklerine göre farklılık göstermektedir.

Araştırma neticesinde genelleme yapılabilmesi için nicel bir çalışma yürütülmüş̧tür. Veri toplama sırasında anket tekniğinden yararlanılmıştır. Pandemi dönemi olması bakımından çevrimiçi ve yüz yüze anketler eş zamanlı olarak uygulanmıştır ve kolayda örnekleme yönteminden faydalanılmıştır.

Uygulanan anket üç bölümden oluşmaktadır. Birinci bölümde 50 yaş ve üstünün seyahat motivasyonlarını ölçmek üzere Sellick'in (2004) 50 yaş ve üstü için hazırlanan "Seyahat Motivasyonu Ölçeği" kullanılmıştır. Bu ölçeğin tercih edilmesindeki en önemli etken çok sayıda boyutun ele alınmış olmasıdır. Çok boyutlu ölçekler madde sayısının fazlalığı sebebiyle veri toplamasını güçleştirse de analiz sonucunda boyutların yeniden düzenlenmesine olanak vermesi bakımından avantaj sağlayabilir ve daha kapsamlı sonuçlar elde edilebilir. Ölçeğin tercih edilmesinin diğer sebebi 50 yaş ve üzeri için hazırlanmış olmasıdır. Ölçeğin kapsam ve yüzey geçerliliğinin ölçülmesi için öncelikle uzman görüşüne başvurulmuştur. Toplamda 48 madde ve 10 boyuttan oluşan ölçeğin İngilizce ve Türkçe ifadeleri 5 uzmanın görüşüne sunulmuştur. Geri dönüşler değerlendirildikten sonra anket formu yeniden düzenlenmiştir. Buna göre üç ifade (2., 25., 27. ifadeler) birden fazla görüş belirttiği için iki farklı ifadeye bölünmüştür. Dört ifade ise (7., 13., 26., 24. ifadeler) mükerrer bulunmuş ve anketten çıkarılmıştır. Sonuç olarak anket 47 ifade ve 10 boyut şeklinde düzenlenmiştir. Sorular (hiç katılmıyorum- kesinlikle katılıyorum aralığında) 5'li Likert tipi anket formunda oluşturulmuştur. Özellikle çevrimiçi anketlerin dikkatle okunup yanitlanması konusunda hassasiyet yaratmak adına bir kontrol sorusu eklenmiştir. 
Anketin ikinci bölümünde seyahat karakteristiğine ilişkin sorulara yer verilmiştir. Derinlemesine inceleme ve kıyaslama fırsatı sağlaması bakımından seyahat karakteristiği sorularının seçimine önem verilmiştir. Kategorik verilerin yer aldığı bu bölümdeki soruların hazırlanmasında Alen, Losada ve Dominguez (2016)'in "Seyahat Karakteristikleri" incelemesinden yararlanılmıştır. Mevcut koşullar gereği bazı veri aralıkları güncellenmiştir. Buna göre konaklama alternatiflerine konukevi, ikincil konutlar ve özellikle pandemiden sonra talep artışı görülen kiralık ev seçenekleri eklenmiştir. "Seyahat edeceğiniz yer ile ilgili nereden fikir alırsınız?" sorusunun cevaplarına "sosyal medya" ifadesi eklenmiştir. Ortalama konaklama süreleri ile ilgili aralık da yine Türkiye'deki paket turlarının süreleri dikkate alınarak revize edilmiştir (www.etstur.com, www.tatilsepeti.com, www.jollytur.com).

Araştırmanın son bölümünde demografik sorulara yer verilmiştir. Bu bölümde konu ile ilgili dört soru sorulmuş, kategorik verilerin değer aralıkları TÜİK'in veri aralıkları dikkate alınarak oluşturulmuş, mevcut koşullar dikkate alınarak bazı revizeler gerçekleştirilmiştir. Buna göre yaş aralı̆̆ı TUIK'deki genel kategori yerine yine TUİK tarafından da kullanılan 5'er yaş aralığına göre düzenlenmiş, başlangıç yaşı alanyazındaki pek çok çalışma ve bu çalışmada ölçeği kullanılan Sellick'in çalışması esas alınarak 50 olarak belirlenmiştir. 50 yaş ve üzeri kişi profili aynı zamanda iş ve aile sorumlulukları bakımından seyahat etmeye daha uygun bir yapıda olduğundan önemli bir pazar olarak değerlendirilmiştir. Araştırma kapsamında hazırlanan anket formu katılımcıların kendileri tarafından cevaplanacağ 1 için TUİK'de eğitim durumunda belirtilen "okuma yazması yok" seçeneği kaldırılmıştır. Ayrıca TÜİK'de çalışma durumu için bulunan "ücretli çalışan" ifadesi "kamu" ve "özel sektör" olarak iki kategoriye ayrılmıştır.

Araştırma kapsamında Türkiye'de yaşayan 50 yaş ve üzerindeki yerli turistler çalışmanın evrenini oluşturmaktadır. Bu bağlamda tesadüfi olmayan örnekleme yöntemlerinden kolayda örneklem kullanılmasına karar verilmiştir. Bu kararın verilmesindeki en büyük sebep yine pandemi nedeniyle ortaya çıkan kısıtlar ve insanların yakın temastan kaçınmasıdır. Araştırmanın bir diğer kısıtını araştırmada pandeminin etkisinin ölçülememesi oluşturmaktadır.

Hazırlanan anket formu 01.03.2021-31.03.2021 tarih aralığında uygulanmıştır. Örneklemin evreni temsil edebilmesi için ulaşılmaya çalışılan örneklem sayısı 384 olarak belirlenmiştir (Büyüköztürk, 2011). Belirtilen tarih aralığında toplamda 522 anket toplanmıştır. Ancak yapılan inceleme sonucunda kontrol sorusuna verilen cevapların uyumsuzluğu ve diğer açık uçlu sorulara verilen yanıtlar dikkate alındığında 130 ankette tutarsızlık tespit edilmiş ve veri setinden çıkartılmıştır. Araştırmada 392 veri değerlendirmeye alınmıştır.

Araştırma verilerinin analizinde SPSS programı kullanılmıştır. Veri setinde ilk olarak Cronbach Alpha iç tutarlılık katsayısına bakılmış, 0.948 ile çalışmanın güvenilir olduğu anlaşılmıştır. Daha sonra veri setinin normal dağılım gösterip göstermediğini belirlemek için çarpıklık (Skewness) ve basıklık (Kurtosis) değerleri incelenmiş, maddelerin çoğunluğunun +2.0,-2.0 değer aralığında, kabul edilebilir aralıkta (George 
ve Malerry, 2010) olduğu görülmüştür. Veri setinde üç maddenin basıklık değeri aralığın üzerinde çıtığı için bu maddelerin normal olasılık grafikleri incelenmiştir. Veri setlerinde normal dağılıma karar verilebilmesi için örneklemin büyüklüğü dikkate alınmalıdır. Küçük ve orta ölçekli örneklemlerde sapmalar daha fazla hissedilebilirken büyük ölçekli örneklemlerde tehdit ortadan kalkar. Buna göre örneklem büyüklüğü 100'den fazla olan çalışmalarda basıklık büyüklüğü ortadan kalkacağı gibi yordamsal testlerden ziyade dağılımın şekline bakmak daha doğru sonuç verir (Tabachnick ve Fidel, 2015: 80). Bu çalışmada da maddelerin dağılım grafikleri incelenerek dağılımın normal olduğu görülmüştür. Bu noktadan sonra verilere parametrik testler uygulanmıştır.

Araştırmanın sonraki aşamasında ölçeğin geçerliliğini belirlemek için faktör analizi yapılmıştır. Analiz sonucuna göre KMO değeri 0.921, anlamlılık değeri .000 (sig <0.05) olarak tespit edilmiştir. Veri setini \%63,878 oranında açıklayan 9 faktöre bölünmüştür. Faktör yükü incelemesinde faktör yük değeri .30 olarak belirlenmiştir (Şencan, 2005). İnceleme sonucunda binişik değerler olduğu tespit edilmiştir. Binişik değer maddenin birden fazla faktörde sahip olduğu yük değerleri arasındaki farkın .10'dan küçük olması olarak açıklanır (Çokluk vd, 2012). Buna göre sırasıyla "Bir gezgin olarak yeteneklerimi geliştirmek için seyahat ederim", "Huzur bulmak için seyahat ederim" ve "Torunlarıma (ve çocuklarıma) tatilde yaşadığım olayları anlatabilmek için seyahat ederim" ifadeleri olmak üzere 3 madde veri setinden çıkarılarak analiz tekrarlanmıştır. Tekrarlanan analizde faktör dağılımı içerik olarak anlamlı bulunmuş, 44 madde ve 8 faktör olarak analizi sonlandırılmıştır. Kategorik verilerin yer aldığı demografik özelliklerle ve seyahat karakteristiği ile ilgili ifadelerde frekans ve yüzdeler hesaplanmıştır. Son olarak hipotezlerin test edilmesinde $t$ testi ve ANOVA kullanılmıştır.

\section{BULGULAR}

Bulgular bölümünde öncelikle ankette yer alan üç bölüm ayrı ayrı gösterilmiştir. Daha sonra hipotez testlerine ilişkin bulgulara yer verilmiştir. Buna göre, katılımcıların demografik özelliklerine ilişkin bulgular Tablo 1'de gösterilmiştir.

Tabloda görüldüğ̈̈ gibi demografik özelliklere göre seyahat eden 50 yaş ve üstü grubun yarısından fazlasının $(\% 52,3)$ 50-54 yaş aralığındakilerden oluştuğu anlaşılmıştır. Bu bulgu alanyazında 50 yaş ve üstünün ileri yaş grubunda sayılmakla birlikte, daha aktif yapıda olduğu varsayımını desteklemektedir. Yaş dağılımı incelendiğinde, yaş arttıkça sayının azaldığı görülmektedir. Özellikle 75 yaş üzerinde seyahat edenlerin sayısının ise yok denecek kadar az olduğu söylenebilir. Bulgularda her ne kadar 90 yaş ve üzeri grupta 2 kişi tespit edilmiş olsa da 80-90 arasında katılımcının bulunmaması ve 90 yaş üzeri sayısının azlığı istisnai bir durum olarak yorumlanabilir. 
Tablo 1. Cevaplayanların demografik özellikleri

\begin{tabular}{lcclcc}
\hline Yaş & $\mathrm{n}$ & $\%$ & Cinsiyet & $\mathrm{n}$ & $\%$ \\
\hline $50-54$ & 205 & 52,3 & Kadın & 227 & 57,9 \\
\hline $55-59$ & 83 & 21,2 & Erkek & 165 & 42,1 \\
\hline $60-64$ & 56 & 14,3 & Çalışma Durumu & $\mathrm{n}$ & $\%$ \\
\hline $65-69$ & 34 & 8,7 & Emekli & 130 & 33,2 \\
\hline $70-74$ & 10 & 2,6 & Ücretli çalışan (Kamu) & 61 & 15,6 \\
\hline $75-79$ & 2 & 0,5 & Ücretli çalışan (Özel sektör) & 60 & 15,3 \\
\hline 90 ve üstü & 2 & 0,5 & Ev işiyle uğraşan & 48 & 12,2 \\
\hline Eğitim & $\mathrm{n}$ & $\%$ & Kendi hesabına çalışan & 44 & 11,2 \\
\hline Yükseköğretim & 20 & 56,1 & Eğ./öğretim alanında çalışan & 28 & 7,1 \\
\hline Lise veya dengi okul mezunu & 98 & 25,0 & Yevmiyeli çalışan & 9 & 2,3 \\
\hline Ortaokul veya dengi okul mezunu & 36 & 9,2 & Ücretsiz aile işçisi & 8 & 2,0 \\
\hline İkokul mezunu & 30 & 7,7 & Çalışamaz halde & 3 & 0,8 \\
\hline Ok- yazma bilip okul bitirmeyen & 8 & 2 & Diğer & 1 & 0,3 \\
\hline
\end{tabular}

Cinsiyet dağılımına bakıldığında bulguların birbirine yakın değerlerde olduğu görülmekle birlikte, araştırmaya katılan kadınların oranının az farkla fazla olduğu görülmektedir. Bu durum kadınların daha fazla seyahat eğiliminde ve serbestliğinde olması ile ilişkilendirilebileceği gibi son yıllarda yükselen bir değer olarak kadınların tek başına seyahat ettikleriyle de ilişkilendirilebilir (Kaba ve Emekli, 2018; Pekiner, 2019). Bu farkın değerlendirilebilmesi için çapraz tablolara bakılması yerinde olacaktır. Demografik verilerden elde edilen diğer çıkarım katılımcıların yarısından fazlasının üniversite ve üstü eğitim almış olmasıdır. Lise ve dengi kişilerin fazlalığı da dikkat çekmektedir. Araştırmaya katılan katılımcıların genel olarak çalışanlar (kamu, özel sektör, kendi işinde, eğitim öğretim sektöründe, yevmiyeli ve ücretsiz aile işçisi) $(\% 53,5)$ olduğu görülmüştür. Araştırma sonucu ve alanyazındaki bilgiler ışığında 50 yaş ve üstünün çalışmasının seyahate bir engel oluşturmadığı söylenebilir.

İleri yaş grubunun seyahat karakteristiği, araştırmanın diğer değişkenidir. Seyahat karakteristiğinin belirlenmesinde pek çok kriter incelenebilmektedir. Bu çalışmada da alanyazında sıkça ele alınan konaklama yeri, seyahat tipi, konaklama süresi, seyahatte kullanılan araç, bilgi kaynağı, kimlerle seyahat ettiği (eşlik durumu) ve seyahatlerinde en çok katıldıkları etkinlikler soru olarak iletilmiştir. Elde edilen veriler Tablo 2' de gösterilmiştir. 
Tablo 2. 50 yaş ve üstü kişilerin seyahat karakteristiği

\begin{tabular}{|c|c|c|c|c|c|}
\hline Konaklama Yeri & $\mathrm{n}$ & $\%$ & Yer Bilgi Kaynağ & $\mathrm{n}$ & $\%$ \\
\hline Otel vb özel konaklama tesisleri & 180 & 45,9 & Aile-arkadaş-komşu tavsiyesi & 144 & 36,7 \\
\hline Aile-arkadaş yanı (evi) & 115 & 29,3 & Sosyal Medya & 116 & 29,6 \\
\hline Misafirhaneler/ Konukevleri & 45 & 11,5 & Medya (gazete, dergi, tv) & 66 & 16,8 \\
\hline İkincil konutlar & 27 & 6,9 & Seyahat Acentaları & 49 & 12,5 \\
\hline Kiralık ev & 16 & 4,1 & Diğer & 17 & 4,3 \\
\hline Diğer & 9 & 2,3 & & & \\
\hline Seyahat Tipi & $\mathrm{n}$ & $\%$ & Eşlik Durumu & $\mathrm{n}$ & $\%$ \\
\hline $\begin{array}{lccr}\text { Kendi başıma, } & \text { birkaç } & \text { yakın } \\
\text { arkadaşımla veya } & \text { çekirdek } & \text { ailemle } \\
\text { gittiğim seyahatler } & & \end{array}$ & 244 & 62,2 & $\begin{array}{l}\text { Eşimle ve diğer aile üyeleriyle } \\
\text { seyahat ederim }\end{array}$ & 146 & 37,2 \\
\hline $\begin{array}{l}\text { Geniş aile ve/veya kalabalık arkadaş } \\
\text { grubumla grubun düzenlendiği özel } \\
\text { turlar }\end{array}$ & 90 & 23 & $\begin{array}{l}\text { Ailemle ve arkadaşlarımla } \\
\text { birlikte seyahat ederim }\end{array}$ & 137 & 34,9 \\
\hline $\begin{array}{l}\text { Acentalarının } \\
\text { çoğunluğunu tanımadığım } \\
\text { çıtığım seyahatler }\end{array}$ & 56 & 14,3 & Arkadaşlarımla seyahat ederim & 53 & 13,5 \\
\hline Diğer & 2 & 0,5 & Yalnız seyahat ederim & 52 & 13,3 \\
\hline Konaklama Süresi & $\mathrm{n}$ & $\%$ & Diğer & 4 & 1 \\
\hline 4-6 gece & 155 & 39,5 & & & \\
\hline 1-2 hafta & 98 & 25 & Etkinlik & $\mathrm{n}$ & $\%$ \\
\hline $1-3$ gece & 87 & 22,2 & Tarihi yerleri ziyaret & 117 & 29,8 \\
\hline 2 hafta üstü & 26 & 6,6 & Yürüyüş & 82 & 20,9 \\
\hline Günübirlik & 23 & 5,9 & Rehberli gezi & 70 & 17,9 \\
\hline Diğer & 3 & 0,8 & Spor & 27 & 6,9 \\
\hline Ulaşım Aracı & $\mathrm{n}$ & $\%$ & Doğal park ziyareti & 26 & 6,6 \\
\hline Özel otomobil & 207 & 52,8 & Diğer & 24 & 6,1 \\
\hline Otobüs & 87 & 22,2 & Müze ziyareti & 14 & 3,6 \\
\hline Uçak & 77 & 19,6 & Konser izleme & 12 & 3,1 \\
\hline Tren & 13 & 3,3 & Galeri vb sanat etkinlikleri & 10 & 2,6 \\
\hline Diğer & 8 & 2 & Dini yerleri ziyaret & 10 & 2,6 \\
\hline
\end{tabular}

Tablo 2 incelendiğinde 50 yaş ve üstü kişilerin genellikle otel ve benzeri özel tesislerde 4-6 gün konaklayan, özel aracıyla seyahat eden, çekirdek aile ve arkadaşlarıyla bireysel seyahatler gerçekleştiren kişiler olduğu görülmüştür. 'Diğer' seçeneğini işaretleyen kişilerin açık uçlu cevapları incelendiğinde seçenekler arasından seçim yapılamadığ için diğeri işaretlediği anlaşılmıştır. Seyahat edilecek yer konusunda en çok dikkate alınanın tavsiyeler ve sosyal medya olduğu ortaya çıkmıştır. Bu noktada ağızdan ağıza pazarlamanın etkisi yanında 50 yaş ve üzerinde sosyal medyanın da 
önemli bir etken olduğu söylenebilir. Farklı olarak iki katılımcı seyahat edilecek yer ile ilgili bilgi kaynağını okuduğu kitaplar olarak belirtmiştir.

Seyahat edilen yerde gerçekleştirilen etkinliklerde 50 yaş ve üstünün tarihi yerleri ziyaret etme, rehberli gezilere katılma, gibi kültürel etkinlikleri tercih ettiği görülmektedir. Ankette ayrıca 'diğer' seçeneği altında 13 kişi hemen hemen bütün etkinliklere katıldığını, yedi kişi yüzdügünü, dört kişi hiçbir etkinliğe katılmadığını (yatmak/deniz tatili gibi) belirtmiştir. Ziyaret edilen yerdeki diğer etkinlikler yürüyüş, spor ve doğal parkları ziyaret gibi fiziksel efor gerektiren uğraşlardır. Bu cevaplar da yine katılımcıların aktif kişiler olduğunu düşündürmektedir. Gerek rehberli geziler gerekse diğer etkinlikler yorucu faaliyetler olup zinde olan kişiler tarafından tercih edilebilir. Bu da yaş dağılımıyla uyumlu olarak değerlendirilebilir.

Araştırmanın son bölümünde temel konu olan seyahat motivasyonu bulguları incelenmiştir. Faktör analizinde Varimax rotasyonu yapılmış, analiz sonrasında oluşan faktörler Tablo 3'te görülmektedir.

Tablo 3.50 yaş ve üstü yerli turistlerin seyahat motivasyonu

\section{İfadeler}

Nostalji ve Değer Paylaşımı

Geçmişime ait güzel anıları tekrar hatırlamak için, 791

seyahat ederim

Bir arkadaşımı veya akrabamı ziyaret etmek için ${ }_{, 772}$ seyahat ederim

Benim için hatırası olan yerleri ziyaret etmek için ${ }_{, 758}$ seyahat ederim

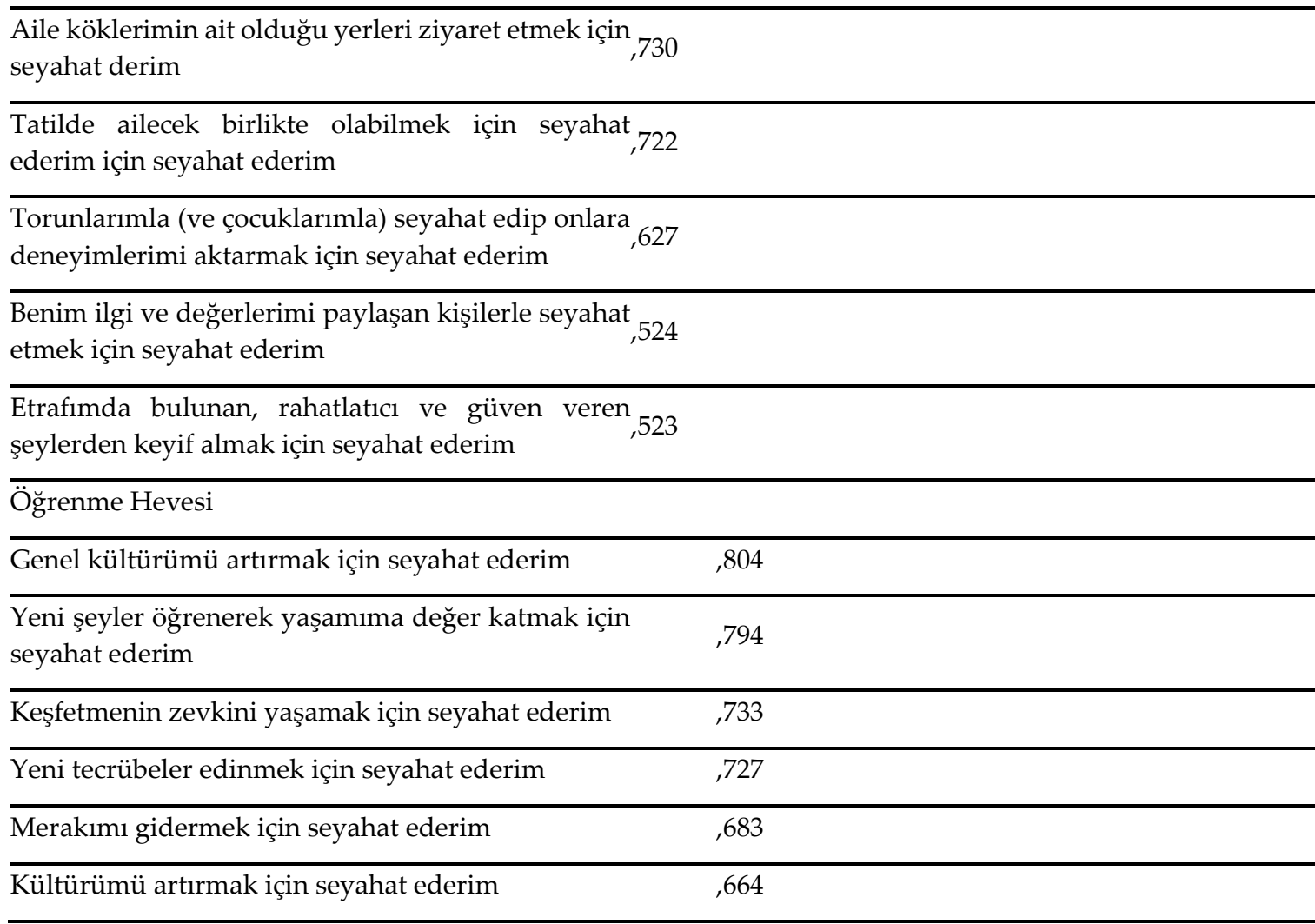




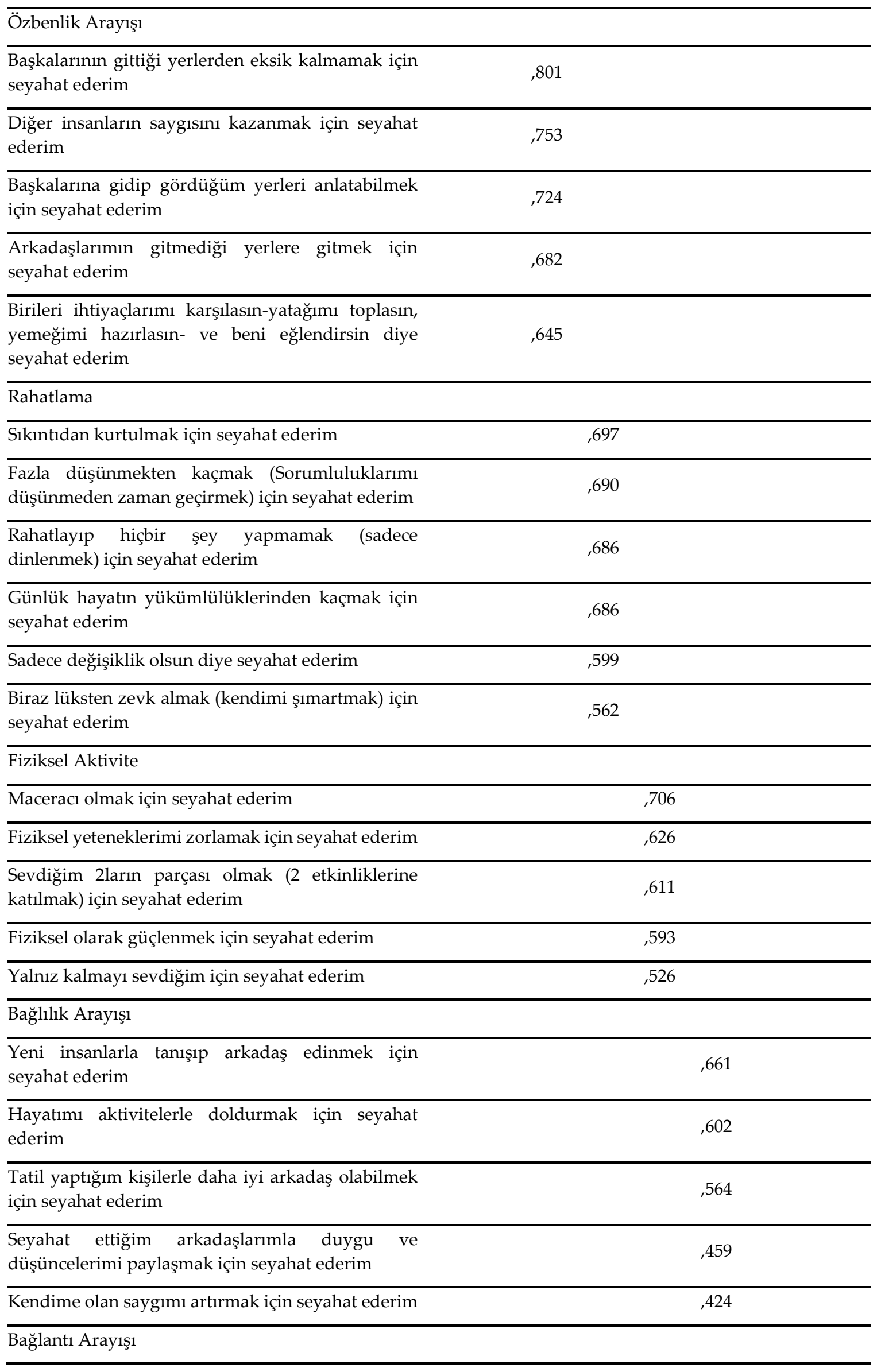




\begin{tabular}{lc}
\hline $\begin{array}{l}\text { Güncel konulardan haberdar olmak için seyahat } \\
\text { ederim }\end{array}$ &, 656 \\
\hline $\begin{array}{l}\text { Başka insanlarla bağlantı kurarak bir topluluğa ait } \\
\text { hissetmek için seyahat ederim }\end{array}$ &, 591 \\
\hline $\begin{array}{l}\text { Toplumla ilgili farkındalığımı artırmak için seyahat } \\
\text { ederim }\end{array}$ &, 559 \\
\hline $\begin{array}{l}\text { Ait olduğum yere bağlılı̆̆ımı geliştirmek için } \\
\text { seyahat ederim }\end{array}$ &, 526 \\
\hline $\begin{array}{l}\text { Yaratıcılığımı ifade edebilecek fırsatlar bulmak için } \\
\text { seyahat ederim }\end{array}$ &, 465 \\
\hline $\begin{array}{l}\text { Maneviyat Arayışı } \\
\text { Kendimi ruhsal anlamda yenilemek için seyahat }\end{array}$ &, 676 \\
ederim &, 675 \\
\hline \begin{tabular}{l} 
Kim olduğumu düşünmek için seyahat ederim \\
\hline Hayatın anlamını düşünmek için seyahat ederim
\end{tabular} \\
\hline $\begin{array}{l}\text { Maneviyat aramak için seyahat ederim } \\
\text { Bartlett’s Test: 9508,209 }\end{array}$
\end{tabular}

Araştırma sonucunda faktör sayısı tahmin edildiği gibi azalmış, Sellick'in 10 faktörde açıkladığı seyahat motivasyonu ölçeği bu çalışmada 8 faktör olarak güncellenmiştir. Dağılımlara bakıldığında ilk faktörün nostaljik anılar arayanlar ve nesiller arası akrabalık arayanlar boyutlarını kapsadığı görülmüştür. Nostalji, geçmişte kalan güzelliklere olan özlem duygusu ve bu duygunun baskın bir duruma gelmesi, geçmişseverlik olarak tanımlanmaktadır (TDK, E.T.: 25.03.2021). Nesiller arası bağlılığın da bir anlamda nostaljiyi içerdiği söylenebilir. Dolayısıyla bu iki faktörün tek boyut altında temsil edilmesi olağan bir sonuç olarak değerlendirilmiştir. Orijinal ölçekte sosyal paylaşım boyutunda yer alan ifade de (benim ilgi ve değerlerimi paylaşan kişilerle seyahat etmek için seyahat ederim) bu boyut altında konumlanmış olup ifadede değer paylaşımı vurgusunun olması bakımından cevaplayanlarca nostaljik bir paylaşım olarak algılanmış olabilir. Bu bulgular dikkate alınarak ilk faktör sekiz ifadeyle ' nostalji ve değer paylaşımı' olarak güncellenmiştir. Yüksek temsil yeteneğine sahip olan diğer faktör orijinal ölçekte öğrenme heveslisi olanlar olarak adlandırılmıştır. Orijinal ölçekte bağlantı ve üstünlük arayanlar boyutunda yer alan bir madde de (kültürümü artırmak için seyahat ederim) bu faktörün altına girmiş olmakla birlikte kültürü artırmak da öğrenme merakı ve hevesiyle ilgili olabileceği için bu uygun olarak değerlendirilmiştir. Böylece öğrenme hevesi boyutu altı ifadeyle temsil edilmiştir.

Seyahat motivasyonunun bir diğer boyutu özbenlik arayışıdır. Benlik TDK'ye göre bir kimsenin öz varlığı, onu kendisi yapan şey, kendi kişiliğine önem verme, kibir ve gurur anlamlarına gelmektedir. Bu çalışmada da orijinal ölçekte verilen özbenlik 
ifadelerine ek olarak rahatına düşkünlük boyutundaki bir ifade (birileri ihtiyaçlarımı karşılasın-yatağımı toplasın, yemeğimi hazırlasın- ve beni eğlendirsin diye seyahat ederim) de bu boyut altında yer almıştır. İfade anlamsal bütünlüğ̈̈ bozmaması ve hatta desteklemesi bakımından özbenlik arayışı boyutu altında değerlendirilmiştir.

Orijinal ölçekte fiziksel aktivite sevenler olarak adlandırılan boyut da büyük oranda aynı ifadelerle temsil edilmiştir. Ek olarak 'maceracı olmak için seyahat ederim' ve 'yalnız kalmayı sevdiğim için seyahat ederim' ifadeleri de bu faktör altında yer almıştır. Maceracı olmak fiziksel aktiviteyle doğrudan ilişkili olduğu için olağan kabul edilmiştir. Fiziksel aktivitelerin bireysel veya gruplarla gerçekleştirilebileceği şeklinde algılanmış olabilir, bu nedenle diğer ifade de fiziksel aktivite boyutu altında anlamlı kabul edilmiştir. Altıncı faktörde orijinal ölçekteki bağlılık arayanlar ile ilgili ifadeler kümelenmiş, buna ek olarak sosyal paylaşım boyutundaki bir ifade ile (yeni insanlarla tanışıp arkadaş edinmek için seyahat ederim) özbenlik boyutundaki bir ifade (kendime olan saygımı artırmak için seyahat ederim) de aynı boyutta açıklanmıştır. Sosyal paylaşım ifadesi bağlılıkla doğrudan ilişkili kabul edilmiştir. Özbenlik ifadesi ise istatistiksel olarak anlamlı bulunduğu için kabul edilmiştir. Sonuç olarak ifade bağhlık arayışı beş ifadeyle temsil edilmiştir.

Ölçekte bağlantı ve üstünlük arayanlar boyutuna ilişkin ifadeler yedinci boyutta temsil edilirken bağlılık arayanlara ilişkin bir ifade de (ait olduğum yere bağlılığımı geliştirmek için seyahat ederim) aynı grupta yer almıştır. Bağlılık ve bağlantı ifadelerinin anlamsal yakınlığı dikkate alınarak bu faktör bağlantı arayışı başlığı altında değerlendirilmiştir. Son boyutta ise ruh ve teselli arayanlara ilişkin ifadeler gruplanmıştır. Orijinal ölçekte beş ifadeyle temsil edilen boyut bu çalışmada maneviyat arayışı başlığı altında 4dört ifadeyle temsil edilmiştir.

Araştırmanın sonraki bölümünde hipotezler test edilmiştir. Buna göre seyahat karakteristiğinin ve seyahat motivasyonunun birbirine ve demografik değişkenlere göre anlamlı bir şekilde farklılaşıp farklılaşmadığı incelenmiştir. İncelemede ikili karşılaştırmalarda t testi, ikiden fazla değişkenin karşılaştırıldığı durumlarda ANOVA uygulanmıştır. Elde edilen bulgular her bir hipotez için ayrı ayrı tablolaştırılmıştır. Analiz aşamasında öncelikle varyansların dağılımı incelenmiş, anlamlılık değerleri bu varyans dağılımına göre değerlendirilmiştir. ANOVA sonucunda anlamlı bulunan sonuçlar Levene değerine bağlı olarak Scheffe ve Tamhane's T2 değerleri incelenerek yorumlanmıştır (Yazıcıoğlu ve Erdoğan, 2004).

Araştırmanın ilk hipotezinde seyahat karakteristiğinin seyahat motivasyonuna göre farklılık gösterip göstermediği incelenmiştir. İncelemede seyahat motivasyonu genel olarak analiz edildikten sonra daha derinlemesine yorumlar yapılabilmesi açısından her bir boyut ayrı ayrı seyahat karakteristiklerine göre analiz edilmiştir. Analize ilişkin bulgular Tablo 4'te verilmiştir. 
Tablo 4. 50 yaş ve üzeri yerli turistlerin seyahat motivasyonları ile seyahat karakteristikleri

\begin{tabular}{|c|c|c|c|c|c|c|c|c|}
\hline & Kon. & Eşlik & $\begin{array}{l}\text { S. } \\
\text { Tipi }\end{array}$ & Bilgi K. & Süre & Ulaşım & Bütçe & Etkinlik \\
\hline GENEL &, $011^{*}$ &, $000^{*}$ &, 529 &, $001^{*}$ &, $002^{*}$ &, $004^{*}$ & 216 &, $000^{*}$ \\
\hline $\begin{array}{lll}\text { Nostalji } & \text { ve } & \text { Değer } \\
\text { Paylaşımı } & & \end{array}$ & 167 & 108 & 177 &, $004^{*}$ &, $030^{*}$ &, $002^{*}$ & 215 &, $002^{*}$ \\
\hline Öğrenme Hevesi &, $003^{*}$ &, $043^{*}$ & 463 &, $005^{*}$ & 203 & 327 &, $000^{*}$ &, $037^{*}$ \\
\hline Özbenlik Arayışı &, $002^{*}$ &, $000^{*}$ &, $001^{*}$ &, $020^{*}$ &, $015^{*}$ &, $000^{*}$ & ,895 &, $000^{*}$ \\
\hline Rahatlama &, $000^{*}$ &, $001^{*}$ & 849 &, $000^{*}$ &, 530 & 198 & 818 &, $000^{*}$ \\
\hline Fiziksel Aktivite &, $000^{*}$ &, $000^{*}$ & ,484 &, $007^{*}$ &, $000^{*}$ &, $002^{*}$ & ,474 &, $000^{*}$ \\
\hline Bağl1lık Arayışı & ,085 &, $000^{*}$ & 107 &, $013^{*}$ & ,060 &, $020^{*}$ & ,591 & 108 \\
\hline Bağlantı Arayışı &, $014^{*}$ &, $000^{*}$ & 189 &, $022^{*}$ &, $001^{*}$ & ,071 & 364 &, $024^{*}$ \\
\hline Maneviyat Arayışı &, $016^{*}$ &, $000^{*}$ &, 533 & ,019* &, $003^{*}$ &, $020^{*}$ &, $035^{*}$ &, $025^{*}$ \\
\hline
\end{tabular}

Tabloda görüldüğü gibi seyahat tipi ve seyahate ayrılan bütçe hariç 50 yaş ve üzeri kişilerin seyahat karakteristiği genel olarak seyahat motivasyonuna göre farklılık göstermiştir. Bir başka ifadeyle $\mathrm{H}_{1}$ hipotezi kabul edilmiştir. Seyahat motivasyonu genel ortalaması üzerinden yapılan analiz sonucunda seyahat motivasyonu ile konaklama ( $F=3,001$, sig=,011), eşlik durumu $(F=7,532$, sig=,000), bilgi kaynağ $(F=4,639$, sig=,001), konaklama süresi $(\mathrm{F}=3,780$, sig=,002), kullanılan ulaşım aracı $(\mathrm{F}=3,895$, sig $=, 004)$ ve seyahatte gerçekleştirilen etkinlik $(\mathrm{F}=4,024=\operatorname{sig}=, 000)$ arasında anlamlı fark olduğu tespit edilmiştir. Daha detaylı inceleme sonucunda seyahat motivasyonunun her bir boyutu ile seyahat karakteristiği ele alınmıştır. Buna göre öğrenme hevesi $(F=3,689)$, özbenlik arayışı $(F=3,766)$, rahatlama $(F=4,755)$, fiziksel aktivite $(\mathrm{F}=5,384)$, bağlantı arayışı $(\mathrm{F}=2,885)$ ve maneviyat arayışı $(\mathrm{F}=2,816)$ boyutları ile konaklama tercihi arasında anlamlı fark olduğu anlaşılmıştır. Yapılan detaylı inceleme sonucunda rahatlama motivasyonuna sahip kişilerin otelde konaklamak yerine arkadaş yanında konaklamayı tercih ettikleri ortalama farkı (mean difference) sonucunda görülmektedir (MD: 0,47). Fiziksel aktiviteyle motive olanların ise hem otel (MD:0,55) hem de misafirhane (MD: 0,76) seçeneği yerine arkadaş yanında konaklamayı tercih ettikleri görülmüştür. Bu sonuç 50 yaş ve üstü seyahat edenlerin arkadaş ve akraba yanında daha rahat hareket ettiği ve muhtemelen yanlarında konakladıkları kişilerle birlikte fiziksel faaliyetlere katıldıkları şeklinde yorumlanabilir. Seyahatin kimlerle gerçekleştirildiği anlamlı farkın görüldüğü diğer bulgudur. Verilere göre 50 yaş ve üstü seyahat edenlerden nostalji ve paylaşım motivasyonu haricinde bütün motivasyon boyutlarının (F=2,482; 5,411; 5,050; 12,741; $6,911 ; 5,956 ; 5,529)$ anlamlı derecede farklı olduğu görülmüştür. Öğrenme hevesi motivasyonuna sahip bireylerin yalnız seyahat etmek yerine diğer seçeneğini tercih ettiği $(\mathrm{MD}=0,61)$ sonuçlardan biridir. İlginç olarak diğer boyutlarda motive olmuş kişiler, yalnız seyahati diğer seçeneklere tercih etmektedir. Burada dikkati çeken özellikle fiziksel aktivite motivasyonuna sahip kişilerin eş ve ailelerine göre yalnız seyahati tercih etme oranı olmuştur $(\mathrm{MD}=1,09)$. Bu sonuç, faktör analizi sonucunda yalnız kalmaya ilişkin ifadenin bu boyut altında değerlendirilmesini de 
desteklemektedir. Seyahat tipi ile seyahat motivasyonunun genel değerlendirmesinde anlamlı bir fark görülmese de özbenlik arayışı boyutunda fark olduğu bulgulardan bir tanesidir $(\mathrm{F}=5,751)$. Araştırma sonucuna göre özbenlik arayışı motivasyonuna sahip kişiler seyahat acentasını tercih etmektedir $(M D=0,63)$. Seyahat acentaları ile gerçekleştirilen gezilerin organizasyon anlamında zahmetsiz geziler olduğu dikkate alındığında faktör analizinde rahatlama ifadesinin bu boyut altında yer almasını olağan kabul edilebilir. Katılımcılara bilgi kaynakları ile ilgili yöneltilen ifade sonuçlarına göre sosyal medya kullanımının diğer bilgi kaynaklarından ayrıldı̆̆ anlaşılmıştır. Motivasyonun öğrenme, rahatlama, fiziksel aktivite ve bağlantı olması durumunda bilgi kaynağı olarak sosyal medya kullanımı aile ve komşu tavsiyesine $(\mathrm{MD}=0,34)$, medyaya $(\mathrm{MD}=0,50,0,58)$ ve diğer kanallarına göre $(\mathrm{MD}=0,96,0,90)$ daha tercih edilir durumda olduğu görülmüştür. Farklı olarak özbenlik motivasyonunda bilgi kaynağı olarak aile ve komşu tavsiyesinin diğer kaynaklara göre daha çok tercih edildiği anlaşılmıştır $(\mathrm{MD}=0,82)$. Bu sonuç özbenlik motivasyonuna ilişkin başkalarının gittiği yerlerden eksik kalmamak, diğer insanların saygısını kazanmak, arkadaşların gittiği yerlere gitmek ve başkalarına gidip gördü yerleri anlatmak ifadeleriyle örtüşür niteliktedir. 50 yaş ve üstünün seyahatlerinde geceleme süresine ilişkin yanıtlarında en çarpıcı sonuç gecelemektense günübirlik seyahatleri tercih etmeleri olmuştur. Özellikle özbenlik (MD=1,73), fiziksel aktivite $(1,04,1,11,0,88,2,36)$, bağlantı arayışı $(\mathrm{MD}=2,26)$ ve maneviyat arayışı $(\mathrm{MD}=2,70)$ motivasyonunda diğer konaklama seçeneklerine göre önemli oranda anlamlı fark tespit edilmiştir. Bu durum genel olarak 50 yaş ve üstünün kısa mesafelerde veya kolay ulaşım imkanları olan destinasyonları tercih ettiği yönünde yorumlanabilir. Öğrenme arayışı, rahatlama ve bağlılık arayışı söz konusu olduğunda ise durum değişmektedir. Ulaşım aracı tercihi bakımından özbenlik, fiziksel aktivite, bağlılık ve maneviyat arayışı söz konusu olduğunda trenin tercih edildiği görülmüştür. Diğer yandan tanımlayıcı verilere bakıldığında trenle seyahat eden kişi sayısının az olduğu da unutulmamalıdır. Bu durumda istatistiksel olarak anlamlı bir fark tespit edilmekle birlikte, genellemenin doğru olmayacağı düşünülmektedir. Bütçeye ilişkin sonuçlar araştırmanın diğer bir önemli sorusudur. Elde edilen bulgulara göre, öğrenme ve maneviyat arayışı söz konusu olduğunda ödemenin daha fazla olabileceği görülmüştür. Seyahat karakteristiğinin belirlenmesi için incelenen son kriter olan seyahatte gerçekleştirilen etkinlik incelemesinde motivasyon boyutlarının çoğunda anlamlı bir fark tespit edilememiştir. Özbenlik arayışı ve fiziksel aktivite söz konusu olduğunda ise ortalama farkları 0,96 ile 1,86 arasında değişen farkların oluştuğu görülmüştür. Bu sonuca göre özbenlik arayışında sporun önemli bir etken olduğu söylenebilir. 
Tablo 5.50 yaş ve üzeri yerli turistlerin seyahat motivasyonları ile demografik özellikleri

\begin{tabular}{lcccc}
\hline & Yaş & Cinsiyet & Ĕ̆itim & Çalışma Durumu \\
\hline GENEL &, $000^{*}$ &, 745 &, $000^{*}$ &, $049^{*}$ \\
\hline Nostalji ve Değer Paylaşımı &, $040^{*}$ &, 594 &, 127 &, 163 \\
\hline Öğrenme Hevesi &, 250 &, $027^{*}$ &, $000^{*}$ &, 268 \\
\hline Özbenlik Arayışı &, $000^{*}$ &, 290 &, $000^{*}$ &, $000^{*}$ \\
\hline Rahatlama &, $000^{*}$ &, 573 &, $006^{*}$ &, $000^{*}$ \\
\hline Fiziksel Aktivite &, $000^{*}$ &, 445 &, $002^{*}$ &, $000^{*}$ \\
\hline Bağlılık Arayışı &, $000^{*}$ &, 978 &, $002^{*}$ &, $006^{*}$ \\
\hline Bağlantı Arayışı &, $004^{*}$ &, 754 &, $027^{*}$ &, $001^{*}$ \\
\hline Maneviyat Arayışı &, $000^{*}$ &, 892 &, 053 &, $016^{*}$ \\
\hline
\end{tabular}

$\mathrm{H}_{2}$ hipotezinde seyahat motivasyonlarının demografik özelliklere göre farklılık gösterip göstermediği incelenmiştir. Analizler sonucunda 50 yaş ve üzeri kişilerin seyahat motivasyonlarının yaş, eğitim ve çalışma durumuna göre farklılık gösterdiği tespit edilmiş; $\mathrm{H}_{2}$ hipotezi kabul edilmiştir. Boyutlara göre incelemelerde dikkati çeken bulgu 50-54 yaş aralı̆̆g ile 90 yaş üstünün özbenlik ve fiziksel aktivite bağlamında daha fazla motive olduklarıdır. Ancak 90 yaş üstünü temsil eden sayısının azlığı dikkate alınarak bu değerlerin yorumlanması doğru bulunmamıştır. 50-54 yaş grubunun sonuçlarına bakıldığında ise özbenlik arayışının $(\mathrm{MD}=0,44,0,71)$, rahatlamanın ( $\mathrm{MD}=0,56,0,75)$ ve fiziksel aktivitenin ( $\mathrm{MD}=0,66,0,88,0,71,1,35)$ daha ileri yaşlara göre daha motive edici olduğu görülmüştür. Bu durumda 50 yaş ve üstünde özellikle 50-54 yaş grubunun diğer gruplara göre daha aktif olduğu söylenebilir. İleri yaşlara göre kendilerini kanıtlama ihtiyaçları da daha yüksektir. Rahatlama motivasyonunun yüksekliği ise emekli sayısının azlı̆̆ıyla açılanabilir. Cinsiyetlere göre sonuçlar incelendiğinde önemli bir fark görülmemekle birlikte sadece öğrenme boyutunda kadınların erkeklere göre öğrenmeye daha hevesli olduğu söylenebilir. Katılımcıların eğitim düzeyinin seyahat motivasyonu ile farkı incelendiğinde sadece nostalji ve değer paylaşımı boyutu ile maneviyat arayışı boyutlarının farklı olmadığı görülmüştür. Dolaysıyla eğitimi ne olursa olsun 50 yaş ve üstü nostalji ve maneviyat söz konusu olduğunda benzer davranışlar sergilemektedir. Diğer boyutlarda istatistiksel olarak anlamlı sonuçlar elde edilmekle birlikte, anlamı çıan kategorilerin temsil sayılarındaki fark dikkate alınarak yorumlanmamıştır. Bu durum çalışma durumu için de geçerlidir. Katılımcıların çalışma durumu ve seyahat motivasyonları arasında anlamlı bir fark tespit edilmiştir. Özellikle nostalji ve değer paylaşımı boyutu ile öğrenme hevesi boyutu dışında kalan bütün boyutlar anlamlı farka sahip olarak tespit edilmiştir ancak kategorilerin temsiliyeti dikkate alınarak değerlendirme yapılmamıştır. 
Tablo 6. 50 yaş ve üzeri yerli turistlerin seyahat karakteristikleri ile demografik özellikleri

\begin{tabular}{lcccc}
\hline & Yaş & Cinsiyet & Eğitim & Çalışma Durumu \\
\hline Konaklama &, $015^{*}$ &, 523 &, 518 &, 066 \\
\hline Eşlik Durumu &, 225 &, 592 &, 061 &, 339 \\
\hline Seyahat Tipi &, 271 &, $023^{*}$ &, 096 &, 503 \\
\hline Bilgi Kaynağ1 &, 557 &, 274 &, 120 &, 537 \\
\hline Geceleme Süresi &, 375 &, 828 &, $015^{*}$ \\
\hline Ulaşım Aracı &, 246 &, $016^{*}$ &, 143 &, $019^{*}$ \\
\hline Ayrılan Bütçe &, 342 &, 915 &, 114 &, 1422
\end{tabular}

Araştırmada son olarak seyahat karakteristiğinin demografik özelliklere göre farklılığ incelenmiştir. Analizler sonucunda seyahat karakteristiği ile demografik özellikler bağlamında birkaç özellik hariç anlamlı fark tespit edilememiştir. $\mathrm{Bu}$ durumda $\mathrm{H}_{3}$ reddedilmiştir. Tablo 6'da görüldüğü gibi yaş değişkeni ile konaklama arasında, cinsiyet ile seyahat tipi ve ulaşım aracı arasında, çalışma durumu ile ulaşım aracı ve bütçe arasında anlamlı fark tespit edilirken eğitimin seyahat karakteristiğinde ayırt edici bir fark yaratmadığı görülmüştür. Çalışma durumunun ulaşım aracı seçiminde ve ayrılan bütçede anlamlı farka sahip olması olağan bir sonuç olarak değerlendirilebilir. Çalışanların seyahatlerine ayırabilecekleri bütçe daha fazla olacağı gibi büyük bir harcama kalemi olan ulaşımda da belirleyici olabilir. Diğer bulgularda ise belirgin farktan söz etmek mümkün değildir.

\section{SONUÇ, TARTIŞMA VE ÖNERILER}

Pandeminin etkilediği alanlardan biri seyahat olmuştur. Ülkeler arası, hatta şehirlerarası seyahatler pandemi dönemindeki kısıtlamaların ilk görüldüğü yerler olmuştur. Ülkeler salgının yaygın olduğu yerlere seyahat kısıtlamaları getirmiş, aşılama olmayan yerlere vize vermemeye başlamıştır (sozcu.com, E.T.: 29 Temmuz 2021). İleride ise potansiyel turistlerin hangi menşeili aşıyı olduklarına kadar detaylı incelemelerin getirileceği konuşulmaktadır (ntv.com, E.T.: 29 Temmuz 2021). Bu noktada turizmde ilk ivmenin yakalanması için iç pazarın önemli bir potansiyel olduğu düşünülmektedir. Bu çalışmada da bu noktadan hareketle iç pazarda bütün yıl seyahat potansiyeline sahip olduğu öngörülen 50 yaş ve üstü incelenmiş, ileri yaş grubunun seyahat motivasyonu, seyahat karakteristiği ve demografik özellikleri irdelenmiştir.

Araştırma sonucunda yerli pazarda 50 yaş ve üstünü en çok motive eden boyutun nostalji ve değer paylaşımı olduğu görülmüştür. Bunu, öğrenme ve özbenlik arayışı izlemektedir. Orijinal ölçekte ise öğrenme ve keşfetme arzusunun daha motive edici olduğu belirtilmiş, nostalji ise arka planda kalan bir motivasyon unsuru olarak tespit edilmiştir. Bu durumda Türkiye'de 50 yaş üstü yerli turistlerin seyahat motivasyonunun farklı olduğu söylenebilir. Diğer taraftan Sert'in (2019) üçüncü yaş grubundaki yerli turistler üzerine yaptı̆̆ı araştırma sonucu ile de tam bir örtüşme sağlanamamıştır. Sert'in çalışmasında itme faktörlerinin başında dinlenme ve 
rahatlama yer almış, bunu sosyal etkileşim ve fiziksel aktivite takip etmiştir. Bu çalışmada ise rahatlama geri planda kalmıştır. Diğer taraftan seyahat karakteristiğine ilişkin sonuçlar değerlendirildiğinde seyahatte gerçekleştirilen etkinlikler bağlamında fiziksel aktivite içeren etkinliklerin tercih sebebi olduğu görülmüştür. Dolayısıyla kısmı bir örtüşme olduğu söylenebilir. Üzerinde durulması gereken bir diğer konu seyahat motivasyonuna ilişkin bu çalışmalar arasındaki farklılığın örneklem kaynaklı mı yoksa pandeminin etkisiyle mi oluştuğunun kesin olarak bilinmemesidir. Aebli vd (2021) Covid 19 sonrasında seyahat motivasyonu üzerine yaptığı araştırmasında fiziksel ve ruhsal iyi olma hali, sosyal bağlanma ihtiyacı, kişisel gelişim ve rahatlamanın hala en önemli motivasyon unsurları olduğunu tespit etmiştir. Diğer taraftan Herzberg'in çift faktör kuramında bahsedildiği gibi hijyen faktörlerinin sağlanmasının motivasyonda ön koşul olduğunun altı çizilmiştir. Bu çalışma pandeminin seyahate engel teşkil olarak algılanmadığını, gerekli önlemlerin alınmasıyla potansiyel kişilerin yine farklı seyahat motivasyonları ile hareket edeceğini göstermiştir. Dolayısıyla bu çalışma sonucunda 50 yaş ve üstü kişiler için belirlenen motivasyon boyutlarının da gerekli sağlık tedbirleri alınması durumunda geçerli olacă̆ varsayılabilir.

Yapılan analizler sonucunda en dikkat çekici bulgulardan biri seyahate kimlerle çıkıldığı konusunda olmuştur. İleri yaş grubu sanılanın aksine daha çok yalnız seyahat etmeyi tercih etmektedir. Ancak seyahat esnasında aile ve arkadaşların ziyaret edilmesi, onların yanında konaklamak, sosyalleşmek ve çeşitli etkinliklere katılmak da istemektedirler. Dolayısıyla bu grubun genel sorumluluklarından uzaklaşmak isteyen ancak sosyalleşmekten de geri durmayan bir grup olduğu söylenebilir. Bir diğer çarpıcı sonuç sosyal medya kullanımıdır. Her ne kadar genel kanı ileri yaş grubunun tavsiyeler sayesinde destinasyonlarla ilgili bilgi aldı̆̆ Confente, 2014) sosyal medya kullanımının esas bilgi kaynağı olduğu görülmüştür. Seyahatlerin süresi konusunda farklı seçeneklere ilgi gösterilmekle birlikte günübirlik geziler en çok tercih edilenler olmuştur. Öğrenme ve maneviyat arayışı söz konusu olduğunda daha çok bütçe ayırıldığı bir diğer önemli bilgidir. İleri yaş grubunda literatürde belirtildiği gibi, yaş ilerledikçe daha pasif bir grup profili ortaya çıkmaktadır. Diğer taraftan özellikle 50 yaş civarının son derece aktif olduğu da araştırma sonucunda tespit edilmiştir. Genç ileri yaş olarak da adlandırılabilecek bu grup çeşitli konularda motive olabilmekte ve aktif bir seyahat planı oluşturabilme potansiyeline sahiptir. Daha ileri yaşlarda ise seyahat motivasyonu düşmekte ve motivasyon boyutlarının belirleyiciliği azalmaktadır.

Elde edilen bu sonuçlar neticesinde ileri yaş grubunun profili gideceği yeri sosyal medyadan aldığ yerine aile ve arkadaş yanında konaklamayı tercih eden, öğrenme ve maneviyat arayışı gibi motivasyon unsurları söz konusu olduğunda harcamaya hevesli, yalnız seyahat eden ancak seyahatlerinde özellikle fiziksel aktiviteler başta olmak üzere çeşitli etkinliklere katılmak isteyen kişilerden oluştuğu görülmüştür. Bu profile göre turizmcilere öncelikle yakın destinasyonların potansiyelini değerlendirmeleri önerilebilir. Örneğin Ankara'da faaliyet gösteren seyahat acentaları 50 yaş ve üstü için 
Beypazarı'na turlar düzenleyebilir. Bununla ilgili duyurumları sosyal medya üzerinden yapabilir. Tur içerisine standart Beypazarı gezisinin yanı sıra, doğa gezisi gibi farklı fiziksel aktivite gerektiren etkinlikler ilave edebilir. Beypazarı'nda mini bir workshop ile telkâri işlemeciliği veya Beypazarı kurusu yapımı eğitimi verilerek daha fazla harcama yapmaları sağlanabilir. Türkiye'nin hemen hemen bütün turizm destinasyonları için buna benzer örneklerin geliştirilmesi mümkündür.

Sonuç olarak, 50 yaş ve üstü yerli turistin önemli bir seyahat potansiyeli olduğu görülmüştür. Özellikle genç ileri yaş grubu için turistik çekicilikler son derece çeşitlidir. Sosyalleşmek, yeni şeyler öğrenmek, daha önce deneyimlenmemiş şeyleri denemek 50 yaş ve üzerinin bir seyahatten beklentileri olarak düşünülebilir. Bir anlamda ikinci baharını yaşayan ileri yaş grubunun en önemli özelliği ne istediğini bilmesidir. Turizmcilerin de bu istekleri karşılaması beklenilen ivmenin sağlanmasında gereklidir. Bu noktada ülkesel değil bölgesel çalışmaların daha faydalı olacağ1 düşünülmektedir.

\section{Hakem Değerlendirmesi: Dış bağımsız.}

Teşekkür: Katkılarından dolayı hakemlere teşekkür ederiz.

Destek Bilgisi: Herhangi bir kurum ve/veya kuruluştan destek alınmamıştır.

Çıkar Çatışması: Yazarlar arasında çıkar çatışması yoktur.

Etik Onayı: Bu çalışmanın tüm hazırlanma süreçlerinde etik kurallara riayet edildiğini yazar(lar) beyan eder. Aksi bir durumun tespiti halinde Güncel Turizm Araştırmaları
Dergisi'nin hiçbir sorumluluğu olmayıp, tüm sorumluluk makale yazar(lar)ina aittir.

Bilgilendirilmiş Onam Formu: Tüm taraflar kendi rızaları ile çalışmaya dâhil olmuşlardır.

Etik Kurul Onayı: Anadolu Üniversitesi Sosyal ve Beşerî Bilimler Araştırma ve Yayın Etiği Kurulundan 03.03.2021 tarih ve 22540 sayılı protokol numarası ile izin alınmıştır.

Araştırmacıların Katkı Oranı: Yazarlar çalışmaya eşit oranda katkı sağlamıştır.

Veri Kullanılabilirlik Beyanı: Araştırma verileri paylaşılmamıştır.

\section{KAYNAKÇA}

Aebli, A., Volgger, M., ve Taplin, R. (2021). A two-dimensional approach to travel motivation in the context of the COVID-19 pandemic, Current Issues in Tourism, 1-16. DOI: 10.1080/13683500.2021.1906631.

Alen, E., Losada, N. ve Dominguez, T. (2016). The impact of ageing on the tourism industry: An approach to the senior tourist profile. Social Indicators Research, 127(1): 303-322.

Anderson, B. B. ve Langmeyer, L (1982). The under-50 and over-50 travelers: A profile of similarities and differences. Journal of Travel Research, 20(Spring), 20-24.

Avcıkurt, C. (2003). Avrupa'da olgun yaş pazarı ve turizme etkileri. Balıkesir Üniversitesi Sosyal Bilimler Enstitüsü Dergisi, 6(9), 141-157.

Ashworth, G. J., ve Tunbridge, J. E. (2005). Moving from blue to grey tourism: Reinventing Malta. Tourism Recreation Research, 30(1), 45-54.

Büyüköztürk, Ş. (2011). Veri Analizi El Kitabı. Ankara: Pegem Akademi. 
Card, J. A. (2003). Aging and disability population trends: Their impact on tourism in the future, e-Review of Tourism Research (eRTR), 1(1), 1-4.

Kreiner, N. C., ve Ram, Y. (2020). National tourism strategies during the Covid-19 pandemic. Annals of Tourism Research, Article in Press, https://doi.org/10.1016/j.annals.2020.103076.

Çokluk, Ö., Şekercioğlu, G. ve Büyüköztürk, Ş. (2012). Sosyal Bilimler İçin Çok Değişkenli İstatistik: SPSS ve Lisrel Uygulamaları. Ankara: Pegem Akademi Yayıncılık.

Dann, G. M. (2002). Senior tourism and quality of life. Journal of Hospitality \& Leisure Marketing, 9(1-2), 5-19.

Diekmann, A., Vincent, M. ve Bauthier, I. (2020). The holiday practices of seniors and their implications for social tourism: A Wallonian perspective. Annals of Tourism Research, 85 (2020) 103096, https://doi.org/10.1016/j.annals.2020.103096.

George, D., ve Mallery, M. (2010). SPSS for Windows Step by Step: A Simple Guide and Reference, 17.0 Update (10a ed.) Boston: Pearson.

Gürsoy, Y. (2016). 50+(Plus) Oteller. Içinde Turizm Pradigmaları, Ed: Erkan Akgöz, (ss:141166), Ankara: Detay Yayıncilik.

Hung, K., ve Lu, J. (2016). Active living in later life: An overview of aging studies in hospitality and tourism journals. International Journal of Hospitality Management, 53, 133-144, http://dx.doi.org/10.1016/j.jhm.2015.10.008.

Jang, S., Bai, B., Hu, C., \& Wu, C. M. E. (2009). Affect, travel motivation, and travel intention: A senior market. Journal of Hospitality \& Tourism Research, 33(1), 51-73.

Kılıçlar, A. Aysen, E. ve Küçükergin, F. (2017). Demografik Değişimlerin Turizm Türleri Üzerindeki Belirleyici Etkisi: Üçüncü Yaş Turizmi. Gazi Üniversitesi Turizm Fakültesi Dergisi, 2017(2): 80-100.

Kozak, M., Acar, D. ve Zencir Çiftçi. E. (2019). Üçüncü yaş turizminin geliştirilmesinde yaşlı dostu şehir (YDŞ) teması. Turizm Akademik Dergisi, 6 (2), 99-114

Moutinho, L. (2000). Trends in tourism. Içinde Strategic management in tourism, Ed: Moutinho, (ss:3-16), CABI Publishing.

Nimrod, G., ve Rotem, A. (2012). An exploration of the innovation theory of successful ageing among older tourists. Ageing and Society, 32(3), 379.

Samancı Tekin, Ç. ve Kara F. (2016). Dünyada ve Türkiye'de yaşlılık, Uluslararası Bilimsel Araştırmalar Dergisi (IBAD), 3(1), 219-229.

Sellick, M. K. (2004). Discovery, connection, nostalgia: Key travel motives within the senior market. Journal of Travel \& Tourism Marjeting, 17(1), 55-71.

Sert, A. N. (2019). Üçüncü yaş yerli turistlerin seyahat kısıtları ve motivasyonları üzerine bir araştırma. Selçuk Üniversitesi Sosyal Bilimler Enstitüsü Dergisi, 2019(42), 200-211.

Şencan, H. (2005). Güvenilirlik ve Geçerlilik. Ankara: Seçkin Yayıncılık.

Tabachnick, B. ve Fidel, L.S. (2015). Çok Değişkenli İstatistiklerin Kullanımı. Ankara: Nobel Yayıncilik. 
Vigolo, V. ve Confente, I. (2013). Older tourists: an exploratory study on online behaviour. In Information and Communication Technologies in Tourism 2014 (pp. 439-452). Springer, Cham.

Wijaya, S., Wahyudi, W., Kusuma, C. B., ve Sugianto, E. (2018). Travel motivation of Indonesian seniors in choosing destination overseas. International Journal of Culture, Tourism and Hospitality Research, 12(2),185-197.

İnternet Kaynakçası

www.turob.org (Erişim Tarihi: 25 Şubat 2021).

https://sozluk.gov.tr/ (Erişim Tarihi: 25 Mart 2021).

www.etstur.com (Erişim Tarihi: 15 Mart 2021).

www.tatilsepeti.com (Erişim Tarihi: 15 Mart 2021).

www.jollytur.com (Erişim Tarihi: 15 Mart 2021).

https://www.icisleri.gov.tr/haziran-ayi-normallesme-tedbirleri-genelgesi (Erişim Tarihi: 28 Temmuz 2021).

https://www.sozcu.com.tr/2021/dunya/asi-yaptirmayan-turke-vize-yok-6207898/ (Erişim Tarihi: 29 Temmuz 2021).

https:/www.ntv.com.tr/galeri/dunya/corona-virus-asisi-olanlar-hangi-ab-ulkelerine-seyahatedebiliyor,V3qycgEVfESCMNJ52LJELQ (Erişim Tarihi: 29 Temmuz 2021).

https://www.tga.gov.tr/guvenli-turizm-programi-belgelendirme-kriterleri/ (Erişim Tarihi: 29 Temmuz 2021). 